\title{
Diagnostic Use of Serum Ferritin Levels to Differentiate Infectious and Noninfectious Diseases in Patients with Fever of Unknown Origin
}

\author{
Mohamed A. Nouh ${ }^{1}$, Hatem M. El Sebaey ${ }^{2}$, Rania S.M. Sobh ${ }^{3}$ \\ ${ }^{1}$ Tropical Medicine Department, Faculty of Medicine, Menoufia University, Egypt. \\ ${ }^{2}$ Medical Biochemistry Department, Faculty of Medicine, Menoufia University, Egypt. \\ ${ }^{3}$ Menouf Fever Hospital,Menouf, Egypt.
}

Corresponding Author

Rania Sami

Mohammed Sobh

Mobile:

01004801687

E mail:

raniasami_ahmed@

yahoo.com

Key words:

Fever of unknown origin, Serum ferritin
Background and study aim: Fever of unknown origin (FUO) constitutes one of the greatest challenges of clinical practice. It's defined as fever more than three weeks with fever above $38.3^{\circ} \mathrm{C}$ on several occasions which remains undiagnosed after 3 days of investigations in the hospital or after three outpatient visits. Measurement of ferritin in serum is unfortunately an underutilized diagnostic test in patients with FUO. Highly elevated serum ferritin levels in patients with FUO should prompt further testing to arrive at a specific diagnosis. The aim of this study is to verify the role of serum ferritin levels in differentiation between fever of unknown origin (FUO) caused by infectious and noninfectious diseases.

Patients and methods: This study included 40 patients with FUO were hospitalized at Menouf Fever Hospital between July 2013 and June 2014, and 20 volunteers of matched age and gender as a control group. According to the final diagnoses, four

\section{INTRODUCTION}

In 1961, Petersdorf introduced a standard definition of FUO. His criteria included fever of temperature more than $38.5^{\circ} \mathrm{C}\left(101^{\circ} \mathrm{F}\right)$ that lasted $\geq$ 3 weeks and remained undiagnosed after 1 week of intensive hospital diagnostic testing [1]. This definition has been renovated to include the outpatient setting (which reflects current medical practice), stipulating: 3 outpatient visits or 3 days in the hospital without elucidation of a cause or 1 week of "intelligent and invasive" ambulatory investigation [2]. The causes of FUO have traditionally been grouped into one of five categories: infections (40-50\%), neoplasm (12- causes were identified, including infectious diseases, malignant diseases, collagen diseases and miscellaneous diseases. Laboratory tests, radiological examination and invasive procedures as bone marrow biopsy and lymph node biopsy were done according to cases. Serum ferritin was measured by Human Ferritin ELISA Kit.

Results: Of the 40 patients, 20 were caused by infectious diseases, 10 were caused by malignant diseases, 7 were caused by collagen diseases and 3 by miscellaneous diseases (two cases of FMF and one case of drug fever). Serum ferritin levels in infectious diseases was lower than that in noninfectious diseases, where it was 457.6 $\mathrm{ng} / \mathrm{mL}( \pm 248.01)$ for the infectious disease group and1241.5 $\mathrm{ng} / \mathrm{mL}( \pm 1163.80)$ for the noninfectious diseases group. Statistically significant difference was found between the two groups $(\mathrm{p}<0.05)$.

Conclusion: An optimal cutoff value of serum ferritin level $>555 \mathrm{ng} / \mathrm{mL}$ can predict FUO caused by a noninfectious disease.

$20 \%)$, collagen vascular diseases (10$15 \%$ ), and numerous miscellaneous diseases (10\%). There's also between 5 and $15 \%$ of FUO cases defy diagnosis, despite exhaustive studies [3]. Physical examination and serologic tests have been used to narrow down the range of diseases and differentially diagnose or exclude possible causes. Ferritin was discovered in 1937 by the French scientist Laufberger, who isolated a new protein from horse spleen that contained up to $23 \%$ by dry weight of iron [4]. In 1972, Addison et al. convincingly demonstrated that ferritin could be reliably detected in human serum [5]. Although it plays important 
roles in iron metabolism and detoxification because it's the primary iron storage mechanism and is critical to iron homeostasis [6,7], it is also used as an acute phase reactant in response to inflammation [8]. When serum ferritin is enhanced (excluding transfusion and hemochromatosis), systemic lupus erythematosus, hematologic malignancy, liver diseases, hemophagocytic syndrome and opportunistic infection by human immunodeficiency virus infection must be considered [9]. Some investigators suggested that serum ferritin may have a diagnostic value for FUO $[10,11]$. So, we aimed to verify the role of serum ferritin levels in differentiation between fever of unknown origin (FUO) caused by infectious and noninfectious diseases.

\section{PATIENTS AND METHODS}

This study was conducted on 40 patients diagnosed with classical FUO, older than 15 years of age, who were hospitalized with fever at Menouf Fever Hospital from July 2013 to June 2014. They were 25 males $(62.5 \%)$ and 15 females $(37.5 \%)$. They were categorized into 3main groups: Group (1) Patients with FUO due to infectious causes, Group (2) Patients with FUO due to non infectious causes and Group (3) 20 healthy volunteers of matched age and gender as a control group. Diagnostic criteria for classical FUO followed the suggestion of Duracket al. [12]. Patients included in this study had a fever more than $38.3^{\circ} \mathrm{C}$, lasting for at least three weeks, of which no causes were identified after three visits to the outpatient care or three days after hospitalization. Patients were excluded from this study if they had FUO related to neutropenia, acquired immunodeficiency syndrome, nosocomial infection or anaemia. All patients will be subjected to the following: Full history taking, Complete clinical examinations and Laboratory tests (Complete blood count, ESR, CRP, urine analysis, stool analysis, renal function tests, liver function tests, Widal agglutination test, Brucella agglutination test,culture of blood, urine and stool, immunological tests, tumour markers, radiological examination and invasive procedures as bone marrow biopsy and lymph node biopsy in suspected cases). Serum ferritin was estimated in all patients and control by Human Ferritin ELISA kit; RAB0197.

\section{Statistical analysis :}

Data were collected, tabulated and statistically analyzed by computer using SPSS version 20 .
The following tests were used; One a way ANOVA ( $F$ test), S Chi-Squared $\left(\chi^{2}\right)$, Fisher's exact test. To evaluate the validity of serum ferritin levels to predict infectious or noninfectious diseases Roc curve (Receiver operating characteristic curve)was used as an index for diagnostic validity,Significance of results ( $\mathrm{P}$ value) was considered if less than 0.05 . The quantitative data which analyzed by Kruskal-Wallis test was expressed as median and range.

\section{RESULTS}

There was no significant difference between the studied groups as regard age and sex (Table 1). There was high significant difference between the studied patients as regard duration of fever preadmission and duration of hospital stay (Table 2). There was no significant difference between the studied patients as regard their clinical picture (Table 3). There was no significant difference between the studied groups as regard complete blood count as shown in (Table 4). There was significant difference between group I and group II $(\mathrm{P}<0.05)$ and high significant difference between both group I and group II with the control group $(\mathrm{P}<0.001)$ as regard ESR (Table 5). There was a high significant difference between group I and control group $(\mathrm{P}<0.001)$, a high significant difference between group II and control group $(\mathrm{P}<0.001)$ with no significant difference between group I and group II ( $\mathrm{p}=$ 0.188 ) as regard CRP (Table 6). There was correlation between ESR, CRP, serum ferritin without statistically significant difference (Tables 7,8). As regard distribution of the studied patients according to their cause of fever it was found that infectious disease group $50 \%$ formed of: brucellosis represented $22.5 \%$, typhoid fever represented $2.5 \%$, TB represented $7.5 \%$, UTI represented $7.5 \%$, infective endocarditis represented $2.5 \%$, hydatid disease represented $2.5 \%$ and malaria represented $5 \%$ of infectious disease group. Noninfectious disease group formed of: Malignant diseases 25\% where Hodgkin lymphoma represented 5\%, non-Hodgkin lymphoma represented 5\%, chronic lymphocytic leukemia represented $7.5 \%$, chronic myeloid leukemia represented 5\%, hepatocellular carcinoma represented $2.5 \%$. Collagen diseases $17.5 \%$ where SLE represented $10 \%$ and rheumatoid arthritis represented $7.5 \%$. Miscellaneous diseases $7.5 \%$ where FMF represented 5\% and drug fever represented $2.5 \%$ (Table 7). As regard serum 
ferritin there was high significant difference between group I and control group $(\mathrm{p}<0.001)$, group II and control group $(\mathrm{p}<0.001)$ and significant difference between group I and group II $(\mathrm{p}<0.05)$ (Table 8$)$. As regard of Validity of the serum ferritin between non-infectious and infectious groups it was found that the optimal serum ferritin cut off point for prediction of a noninfectious disease in patients with FUO was $555 \mathrm{ng} / \mathrm{ml}$ (Table 9). Roc curve for serum ferritin between non-infectious and infectious groups shown in figure (1).

Table (1): Comparison between age and sex of the studied groups

\begin{tabular}{|c|c|c|c|c|c|c|c|c|}
\hline & \multicolumn{6}{|c|}{ Groups } & \multirow{3}{*}{$\begin{array}{c}\text { Test of } \\
\text { significance }\end{array}$} & \multirow{3}{*}{ P-value } \\
\hline & \multicolumn{2}{|c|}{$\begin{array}{c}\text { Infectious (I) } \\
(\mathbf{N}=\mathbf{2 0})\end{array}$} & \multicolumn{2}{|c|}{$\begin{array}{l}\text { Non-infectious (II) } \\
(\mathbf{N}=\mathbf{2 0})\end{array}$} & \multicolumn{2}{|c|}{$\begin{array}{l}\text { Controls (III) } \\
(\mathrm{N}=\mathbf{2 0})\end{array}$} & & \\
\hline & No & $\%$ & No & $\%$ & No & $\%$ & & \\
\hline $\begin{array}{l}\text { Age } \\
\text { Mean } \pm \mathrm{SD}\end{array}$ & \multicolumn{2}{|c|}{$34.80 \pm 9.33$} & \multicolumn{2}{|c|}{$39.85 \pm 13.53$} & \multicolumn{2}{|c|}{$33.0 \pm 7.01$} & $\begin{array}{c}\text { Kruskal-Wallis } \\
=3.26\end{array}$ & $\mathrm{P}=0.195$ \\
\hline $\begin{array}{l}\text { Sex } \\
\text { Male } \\
\text { Female }\end{array}$ & $\begin{array}{c}11 \\
9\end{array}$ & $\begin{array}{l}55.0 \\
45.0\end{array}$ & $\begin{array}{c}12 \\
8\end{array}$ & $\begin{array}{l}60.0 \\
40.0\end{array}$ & $\begin{array}{c}12 \\
8\end{array}$ & $\begin{array}{l}60.0 \\
40.0\end{array}$ & $\chi^{2}=0.10$ & $\mathrm{P}=0.749$ \\
\hline
\end{tabular}

Table (2): Comparison between the studied patients regarding duration of the present illness

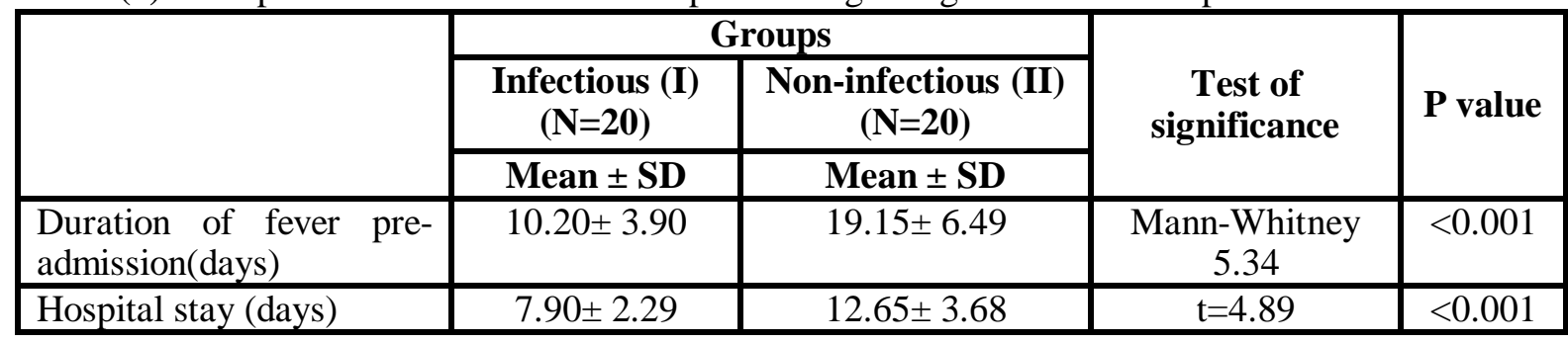

Table (3): Comparison between the studied patients regarding their clinical picture

\begin{tabular}{|c|c|c|c|c|c|c|}
\hline & \multicolumn{4}{|c|}{ Groups } & \multirow{3}{*}{ Test } & \multirow{3}{*}{ P-value } \\
\hline & \multicolumn{2}{|c|}{$\begin{array}{c}\text { Infectious (I) } \\
(\mathbf{N}=\mathbf{2 0})\end{array}$} & \multicolumn{2}{|c|}{$\begin{array}{c}\text { Non-infectious (II) } \\
(\mathrm{N}=\mathbf{2 0})\end{array}$} & & \\
\hline & No & $\%$ & No & $\%$ & & \\
\hline Arthralgia & 3 & 15.0 & 8 & 40.0 & $\chi^{2}=3.13$ & 0.077 \\
\hline Myalgia & 5 & 25.0 & 11 & 55.0 & $\chi^{2}=3.75$ & 0.0 .053 \\
\hline Weight loss & 0 & 0.0 & 4 & 20.0 & $\chi^{2}=3.10$ & 0.106 \\
\hline Hepato-splenomegaly & 2 & 10.0 & 2 & 10.0 & $\chi^{2}=0.36$ & 1.0 \\
\hline Lymphadenopathy & 0 & 0.0 & 4 & 20.0 & $\chi^{2}=3.10$ & 0.106 \\
\hline Cardiac murmur & 1 & 5.0 & 0 & 0.0 & $\chi^{2}=1.02$ & 1.0 \\
\hline
\end{tabular}

Table (4): Comparison between the studied groups as regard complete blood count

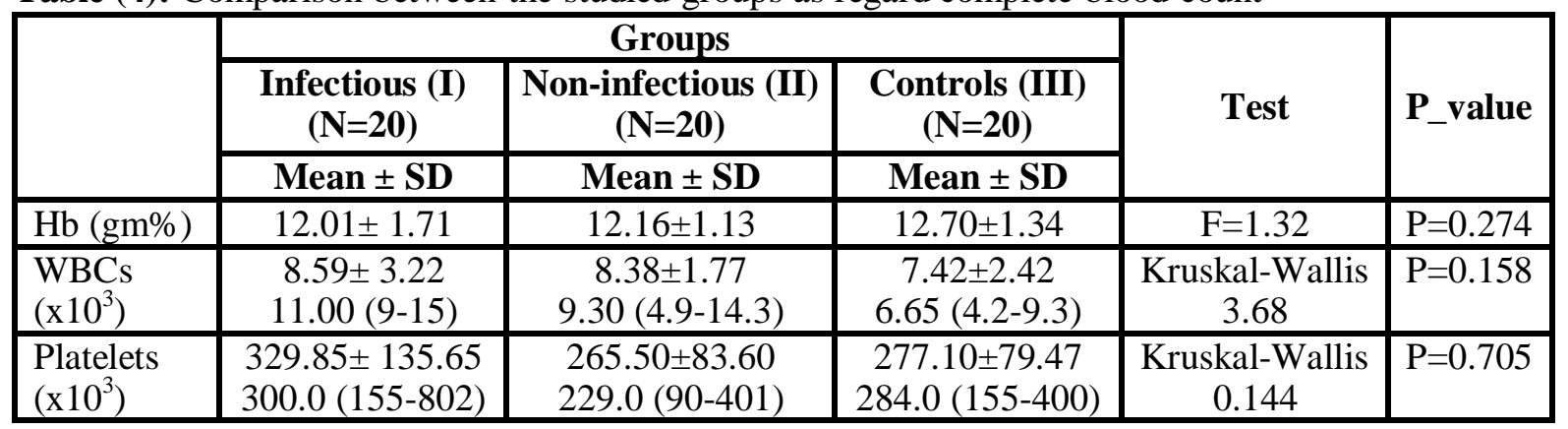


Table (5): Comparison between the studied groups as regard ESR

\begin{tabular}{|c|c|c|c|c|c|}
\hline & \multicolumn{3}{|c|}{ Groups } & \multirow{3}{*}{$\begin{array}{c}\text { Kruskal- } \\
\text { Wallis } \\
\text { Test }\end{array}$} & \multirow{3}{*}{ P_value } \\
\hline & $\begin{array}{c}\text { Infectious (I) } \\
(\mathbf{N}=\mathbf{2 0})\end{array}$ & $\begin{array}{c}\text { Non-infectious (II) } \\
(\mathrm{N}=20)\end{array}$ & $\begin{array}{c}\text { Controls (III) } \\
(\mathbf{N}=20)\end{array}$ & & \\
\hline & Mean \pm SD & Mean \pm SD & Mean \pm SD & & \\
\hline $\operatorname{ESR}(\mathrm{mm} / \mathrm{h})$ & $\begin{array}{l}36.60 \pm 23.86 \\
22.0(10-75)\end{array}$ & $\begin{array}{c}72.05 \pm 30.11 \\
84.0(10-110)\end{array}$ & $\begin{array}{l}13.10 \pm 3.90 \\
13.5(6-19)\end{array}$ & $\begin{array}{c}0.1431 .92 \\
\mathrm{P}<0.001\end{array}$ & $\begin{array}{c}\mathrm{P} 1=0.01 \\
\mathrm{P} 2<0.001 \\
\mathrm{P} 3<0.001\end{array}$ \\
\hline
\end{tabular}

Table (6): Comparison between the studied groups as regard CRP

\begin{tabular}{|l|c|c|c|c|c|}
\hline \multirow{2}{*}{} & \multicolumn{3}{|c|}{ Groups } & \multirow{2}{*}{ Test } & \multirow{2}{*}{$\begin{array}{c}\text { Post hoc } \\
\text { value }\end{array}$} \\
\cline { 2 - 4 } & $\begin{array}{c}\text { Infectious (I) } \\
(\mathbf{N = 2 0})\end{array}$ & $\begin{array}{c}\text { Non-infectious (II) } \\
(\mathbf{N = 2 0})\end{array}$ & $\begin{array}{c}\text { Controls (III) } \\
(\mathbf{N = 2 0})\end{array}$ & & \\
\cline { 2 - 4 } & Mean \pm SD & Mean \pm SD & Mean \pm SD & & \\
\hline CRP & $17.10 \pm 12.46$ & $11.68 \pm 5.81$ & $4.48 \pm 0.88$ & Kruskal-Wallis & P1 $=0.188$ \\
$(\mathrm{mg} / \mathrm{dL})$ & $12.00(6-56.0)$ & $9.05(2.40-20)$ & $4.9(2.9-5.4)$ & 29.37 & $\mathrm{P} 2<0.001$ \\
& & & & $\mathrm{P}<0.001$ & $\mathrm{P} 3<0.001$ \\
& & & & & \\
\hline
\end{tabular}

Table (7): Correlation between Serum ferritin and ESR among the studied groups

\begin{tabular}{|l|c|c|c|c|c|c|}
\hline \multirow{2}{*}{} & \multicolumn{6}{|c|}{ Serum ferritin } \\
\cline { 2 - 7 } & \multicolumn{2}{|c|}{ Infectious } & \multicolumn{2}{c|}{ Non-infectious } & \multicolumn{2}{c|}{ Controls } \\
\cline { 2 - 7 } & $\mathbf{r}$ & P value & $\mathbf{r}$ & P value & $\mathbf{r}$ & P value \\
\hline \multirow{2}{*}{ ESR } & 0.19 & 0.411 & 0.01 & 0.996 & 0.01 & 0.996 \\
\hline
\end{tabular}

Table (8): Correlation between Serum ferritin and CRP among the studied groups

\begin{tabular}{|l|c|c|c|c|c|c|}
\hline \multirow{2}{*}{} & \multicolumn{9}{|c|}{ Serum ferritin } \\
\cline { 2 - 7 } & \multicolumn{2}{|c|}{ Infectious } & \multicolumn{2}{c|}{ Non-infectious } & \multicolumn{2}{c|}{ Controls } \\
\cline { 2 - 7 } & $\mathbf{r}$ & P value & $\mathbf{r}$ & P value & $\mathbf{r}$ & P value \\
\hline CRP & 0.22 & 0.180 & 0.02 & 0.912 & 0.02 & 0.912 \\
\hline
\end{tabular}


Table (9): Distribution of the studied patients regarding their cause of fever

\begin{tabular}{|c|c|c|}
\hline & & atients $(\mathrm{N}=40)$ \\
\hline & No & $\%$ \\
\hline Infectious diseases & 20 & 50 \\
\hline Brucellosis & 9 & 22.5 \\
\hline Typhoid & 1 & 2.5 \\
\hline $\mathrm{TB}$ & 3 & 7.5 \\
\hline UTI & 3 & 7.5 \\
\hline Infective endocarditis & 1 & 2.5 \\
\hline Hydatid disease & 1 & 2.5 \\
\hline Malaria & 2 & 5.0 \\
\hline Non infectious diseases & & \\
\hline Malignant diseases & 10 & 25 \\
\hline Hodgkin lymphoma & 2 & 5.0 \\
\hline Non- Hodgkin lymphoma & 2 & 5.0 \\
\hline Chronic lymphocytic leukemia & 3 & 7.5 \\
\hline Chronic myeloid leukemia & 2 & 5.0 \\
\hline Hepatocellular carcinoma & 1 & 2.5 \\
\hline Collagen diseases & 7 & 17.5 \\
\hline SLE & 4 & 10.0 \\
\hline Rheumatoid artheritis & 3 & 7.5 \\
\hline Miscellaneous diseases & 3 & 7.5 \\
\hline FMF & 2 & 5.0 \\
\hline Drug fever & 1 & 2.5 \\
\hline
\end{tabular}

Table (10): Distribution of the studied groups regarding serum ferritin level

\begin{tabular}{|c|c|c|c|c|c|}
\hline & \multicolumn{3}{|c|}{ Groups } & \multirow{3}{*}{$\begin{array}{c}\text { Kruskal- } \\
\text { Wallis } \\
\text { test }\end{array}$} & \multirow{3}{*}{$\begin{array}{c}\text { Post hoc } \\
\text { value }\end{array}$} \\
\hline & $\begin{array}{c}\text { Infectious } \\
(\mathbf{I}) \\
(\mathbf{N}=\mathbf{2 0}) \\
\end{array}$ & $\begin{array}{c}\text { Non-infectious } \\
\text { (II) } \\
(\mathbf{N}=\mathbf{2 0})\end{array}$ & $\begin{array}{c}\text { Controls } \\
\text { (III) } \\
(\mathbf{N}=\mathbf{2 0}) \\
\end{array}$ & & \\
\hline \multirow[b]{2}{*}{$\begin{array}{l}\text { Serum ferritin } \\
(\mathrm{ng} / \mathrm{ml})\end{array}$} & Mean \pm SD & Mean \pm SD & Mean \pm SD & & \\
\hline & $\begin{array}{c}457.60 \\
\pm 248.01 \\
455.0(150-950)\end{array}$ & $\begin{array}{c}1241.50 \\
\pm 1163.80 \\
854.0(77-4810)\end{array}$ & $\begin{array}{c}96.05 \\
\pm 45.21 \\
88(37-201)\end{array}$ & $\begin{array}{c}35.42 \\
\mathrm{P}<0.001(\mathrm{HS})\end{array}$ & $\begin{array}{l}\mathrm{P} 1=0.007 \\
\mathrm{P} 2<0.001 \\
\mathrm{P} 3<0.001\end{array}$ \\
\hline
\end{tabular}

Table (11): Validity of the serum ferritin between non-infectious and infectious groups

\begin{tabular}{|l|c|c|c|c|c|c|c|c|c|}
\hline Variable & AUC & $\begin{array}{c}\text { Cutoff } \\
\text { point }\end{array}$ & SE & Sig & Sensitivity & Specificity & PPV & NPV & Accuracy \\
\hline $\begin{array}{l}\text { Serum } \\
\text { ferritin }\end{array}$ & $74.9 \%$ & 555 & 0.08 & 0.007 & $70 \%$ & $80 \%$ & $77.8 \%$ & $72.7 \%$ & $75 \%$ \\
\hline
\end{tabular}






Fig (1) : Roc curve for serum ferritin between non-infectious and infectious groups

\section{DISCUSSION}

Despite recent advances in diagnostic techniques, fever of unknown origin (FUO) remains a formidable challenge. It's frustrating for patients and physicians because the diagnostic workup often involves numerous noninvasive and invasive procedures that sometimes fail to explain the fever [12]. Although diagnostic methods using a specific algorithm have been proposed to minimize unnecessary tests in patients with FUO, a universal test has not yet been developed [13]. In previous studies, the causes of FUO have been classified as infectious diseases, malignancies, collagen diseases, and others [14]. Interest in utilization of serum ferritin as a clinical tool for diagnosis of human diseases has increased [15]. Although serum ferritin may be increased in patients with fever, such an increase might become a factor in differential diagnosis of FUO rather than an acute-phase reactant, considering that the diagnosis criterion for FUO is a fever lasting longer than 3 weeks [16].

In this study, serum ferritin level was found significantly elevated in noninfectious diseases than in infectious diseases $(\mathrm{p}<0.05)$. This agrees with Seong et al. [16] who reported significant difference between infectious and noninfectious diseases $(\mathrm{p}<0.05)$.

This study reported that at serum ferritin cut off value $555 \mathrm{ng} / \mathrm{mL}$ (with sensitivity $70 \%$, specifity $80 \%$ and AUC $74.9 \%$ ) in patients with FUO corresponded to a low probability of the presence of an infectious disease and a high probability of noninfectious disease (malignant or collagen).This agrees with Seong et al. [16] who reported that serum ferritin level $(>561 \mathrm{ng} / \mathrm{mL})$ in patients with FUO corresponded to a low probability of the presence of an infectious disease and a high probability of noninfectious disease.Also Cunha [10] reported that highly elevated serum ferritin levels $(>500 \mathrm{ng} / \mathrm{ml})$ in a FUO patient combined with other clues from the history and physical examination should easily eliminate infections and focus the subsequent work-up to determine the etiology among rheumatic or neoplastic disorders. While, fstathiou et al. [17] suggested that low ferritin concentrations $(<500 \mathrm{ng} / \mathrm{mL})$, eosinopenia (< 40/mm3), and high CRP (CRP > 6mg/dL) were associated with infectious diseases.

Burke and Andrew [18] found that highly elevated ESR (>100 mm/hour), highly elevated/sustained ferritin levels, highly elevated LDH and highly elevated alkaline phosphatase levels with CBC (pancytopenia, leucopenia, relative lymphopenia and thrombocytosis) suggest FUOs attributable to malignancy.

Finally we can conclude that serum ferritin with cut off value $555 \mathrm{ng} / \mathrm{mL}$ in patients with FUO corresponded to high probability of noninfectious disease (malignant or collagen disease), so it may help in differentiation between infectious and noninfectious causes of FUO. However, multicentric studies with large number of patients are needed to establish the role of serum ferritin in FUO. 
Funding: None.

Conflicts of interest: None.

Ethical approval: Approved.

\section{REFERENCES}

1- Petersdorf RG and Beeson P. Fever of unexplained origin, report of 100 cases. Medicine (Baltimore) 1961;40:1-30.

2- KnockaertDC. Recurrent fevers of unknown origin. Infect Dis Clin North Am 2007; 21 (4): 1189-211.

3- Salah SE , Abdel Wahab MF: Tropical medicine and infectious diseases. Second edition: 1995; 234-235.

4- Laufberger V. Sur la cristallisation de la ferritine, Bull. Soc. chim. biol. 1937, 19: 1575-1582.

5- Jacobs A, Worwood M.. Ferritin in serum. Clinical and biochemical implications. $N$ Engl $J$ Med. 1975; 292:951-956.

6- Koorts AM,Viljoen M. Acute Phase Proteins: Ferritin and Ferritin Isoforms, Acute Phase Proteins - Regulation and Functions of Acute Phase Proteins, Prof. Francisco Veas (Ed.) 2011; (7) 153-184.

7- Harrison PM, Arosio P. The ferritins: molecular properties, iron storage function and cellular regulation. Biochim Biophys Acta.1996 ; 1275(3): 161-203.

8- Tran TN, Eubanks SK, Schaffer KJ, Zhou CY, Linder MC. Secretion of ferritin by rat hepatoma cells and its regulation by inflammatory cytokines and iron. Blood 1997; 90:4979-86.

9- Koduri PR, Carandang G, DeMarais P, Patel AR. Hyperferritinemia in reactive hemophagocytic syndrome report of four adult cases. Am J Hematol, 1995; 49:247-9.

10- Cunha BA. Fever of unknown origin (FUO): diagnostic importance of serum ferritin levels. Scand J Infect Dis 2007; 39:651- 2.

11- Durack DT, Street AC. Fever of unknown origin - reexamined and redefined. Curr Clin Top Infect Dis 2005; 11: 35-51.
12- Agarwal PK, Gogia A. Fever of Unknown Origin. JAPI VOL. 52: 2004; 314-318.

13- Bleeker-Rovers CP,Vos FJ, de Kleijn EM, Mudde AH, Dofferhoff TS \& Richter C: A prospective multicenter study on fever of unknown origin: the yield of a structured diagnostic protocol. Medicine. 2007; 86:26-38.

14- Vanderschueren S, Knockaert D, Adriaenssens T, Demey W, Durnez A , Blockmans D. From prolonged febrile illness to fever of unknown origin: the challenge continues. Arch Inrern Med. 2003; 163:1033-41.

15- Wang W, Knovich MA, Coffman LG, Torti FM , Torti SV: Serum ferritin: Past, present and future. Biochimicaet Biophysica Acta. 2010; 1800: 7609.

16- Kima SE, Kima UJ, Janga MO, Kanga SJ, Janga HC, Junga SI et al. Diagnostic use of serum ferritin levels in FUO. Disease Markers. 2013; 34: 211-218.

17-Efstathiou SP, Pefanis AV, Tsiakou AG, Skeva II, TsioulosDI, Achimastos AD et al. Fever of unknown origin: discrimination between infectious and non-infectious causes. Eur J Intern Med. 2010; 21:137-43.

18-Cunha BA, Petelin A. Fever of unknown origin (FUO) due to large B-cell lymphoma: The diagnostic significance of highly elevated alkaline phosphatase and serum ferritin levels. Heart and Lung 2013:42: 67-71.

Peer reviewer: Noha Shaheen, Assistant Professor of Tropical Medicine and Hepatogastroenterology, Faculty of Medicine, Zagazig University, Egypt. Editor:Tarik Zaher,Pofessor of Tropical Medicine and Hepatogastroenterology, Faculty of Medicine, Zagazig University, Egypt. 